\section{University of New Hampshire}

Carsey School of Public Policy

\section{CARSEY}

National Issue Brief \#74
RESEARCH

Summer 2014

\title{
Related Foster Parents Less Likely to Receive Support Services Compared With Nonrelative Foster Parents
}

\author{
Wendy A. Walsh and Marybeth J. Mattingly
}

$\mathrm{T}$ This brief identifies gaps in support services among foster parents using data from a nationally representative survey of children involved in the child welfare system. Access to adequate support services for foster parents is important to ensure that children in care are well nurtured. Furthermore, adequate support services are important for encouraging foster parents to continue fostering, thereby encouraging continuity of relationships with their foster children. ${ }^{1}$ Yet, little is known about the extent to which formal, and particularly, informal kinship foster parents use particular types of support services compared with nonrelative foster parents. Understanding differences by type of foster parent will help child welfare decision makers identify whether access to support services should be improved.

When Child Protective Services has determined that a child has been abused or neglected and believes that a child will be unsafe in her/his home, it places the child in a substitute care arrangement. ${ }^{2}$ These include nonrelative foster care, formal kinship foster care (the state has legal custody and places the child with a family member), informal kinship foster care (a parent voluntarily places a child with a family member without court involvement), or group homes or other out-of-home settings, such as emergency shelters or residential programs. ${ }^{3}$ States are required to seek the least restrictive, most family-like setting for out-of-home placements. ${ }^{4}$ When Child Protective Services helped place the child in informal care, the states should know who informal caregivers are and should be able to offer them support services, but in other cases a family may voluntarily place a child without state knowledge or court involvement. The data used in this analysis are from a sample of children who had a maltreatment report, and thus in most cases the state should have a record of who the informal caregiver is, although in some cases the informal foster care may have been arranged by the family after the investigation was complete and the

\section{KEY FINDINGS}

The percentage of foster parents who received recent support services (within a six month timeframe) varies dramatically by foster placement and support service type.

Kinship foster parents (both formal and informal) in all households regardless of poverty status are less likely to have received training, used respite care, or participated in peer support groups in the past six months compared with nonrelative foster parents.

case was closed. Examples of support services include instruction or training, peer support groups, and respite care (that is, short-term relief for foster parents and a temporary safe haven for a child). ${ }^{5}$

Because research has established that formal kinship caregivers (that is, court involved) are more likely to be poor compared to nonrelative foster parents, this brief focuses on support services among foster parents in poor households and nonpoor households.

\section{Kinship Foster Parents Use Fewer Support Services}

Among foster parents in poor households, formal and informal kinship foster parents were significantly less likely to have received any special instruction or training in skills to be a foster parent within a six month time frame compared with nonrelative foster parents. Informal kinship foster parents had the lowest rates of receiving training (16 percent) and nonrelative foster parents had the highest rates (71 percent). Twenty-four percent of formal kinship foster parents received training. This training included topics such as how to deal with problems with their foster child or behavior management techniques (see Figure 1). 


\section{FIGURE 1: PERCENTAGE OF FOSTER PARENTS IN POOR HOUSEHOLDS RECEIVING RECENT (PAST SIX MONTHS) SERVICES BY TYPE OF PLACEMENT}

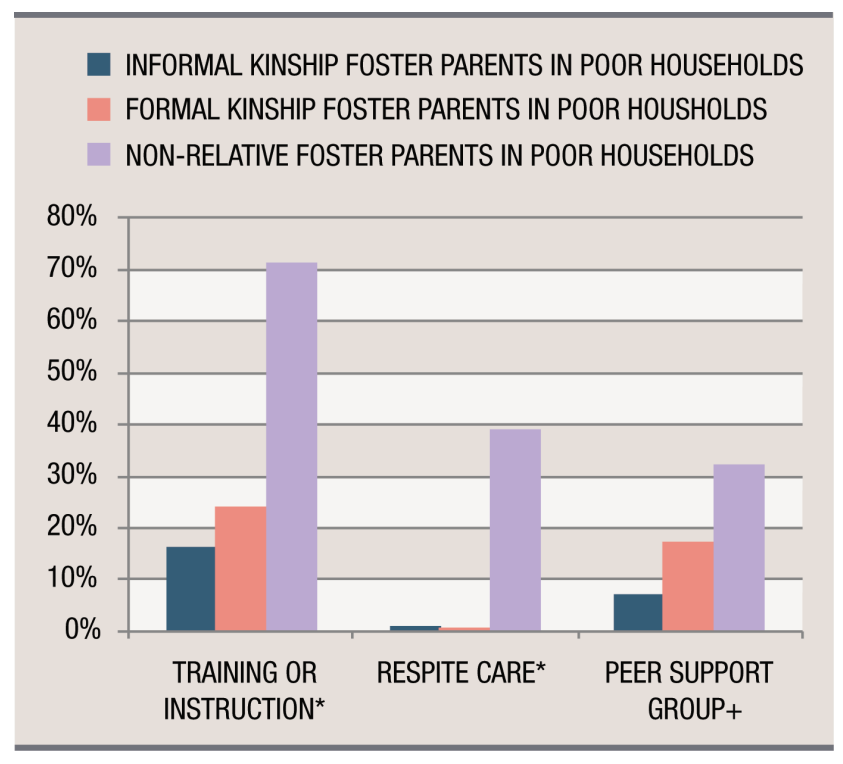

Notes: 1) *Asterisk indicates statistically significant difference $p<.05 ;+p=.058$. 2) Poor household is defined as less than 100 percent of federal poverty level; nonpoor is greater than 100 percent of federal poverty level.

Kinship foster parents, either formal (0 percent) or informal ( 1 percent), were also less likely to receive respite care than nonrelative foster parents (39 percent). Kinship foster parents, either formal (17 percent) or informal (7 percent), were somewhat less likely to be involved with any organized peer support groups than nonrelative foster parents (32 percent).

Similarly, formal and informal kinship foster parents in nonpoor households were significantly less likely to have recently used support services compared with nonrelative foster parents (see Figure 2).

These differences among foster parents in nonpoor households include:

- Any special training (17 percent of formal kinship, 3 percent of informal kinship, and 71 percent of nonrelative foster parents)

- Use of respite care (16 percent of formal kinship, 0 percent of informal kinship, and 23 percent of nonrelative foster parents)

- Use of peer support groups (9 percent of formal kinship, 3 percent of informal kinship, and 40 percent of nonrelative foster parents)

Generally, foster parents in poor households had rates of support services equal to those in nonpoor households. However, formal kinship foster parents in nonpoor households had higher rates of respite care
FIGURE 2: PERCENTAGE OF FOSTER PARENTS IN NONPOOR HOUSEHOLDS RECEIVING RECENT (PAST SIX MONTHS) SERVICES BY TYPE OF PLACEMENT

INFORMAL KINSHIP FOSTER PARENTS IN NONPOOR HOUSEHOLDS

FORMAL KINSHIP FOSTER PARENTS IN NONPOOR HOUSHOLDS

NON-RELATIVE FOSTER PARENTS IN NONPOOR HOUSEHOLDS

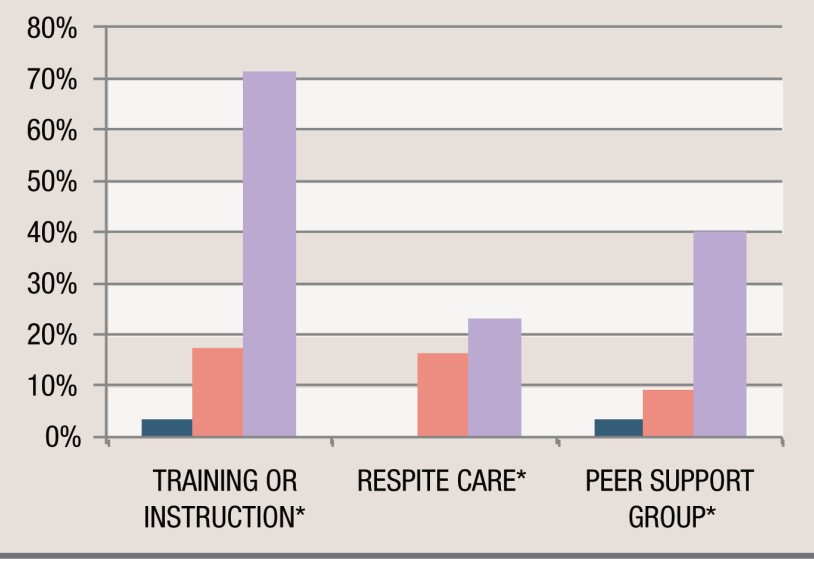

Notes: 1) *Asterisk indicates statistically significant difference $p<.05$.

2) Poor household is defined as less than 100 percent of federal poverty level; nonpoor is greater than 100 percent of federal poverty level.

compared to those in poor households. Informal kin in poor households had higher rates of special training and use of peer support groups compared to those in nonpoor households.

\section{More Support Services Are Needed for Foster Parents, Particularly Kinship Parents}

The findings highlight the need to pay attention to the type and availability of support services for all foster parents. Kinship foster parents were less likely than nonrelative foster parents to receive training, respite care, and use of peer support groups within the past six months, regardless of poverty status. Generally foster parents in poor households had higher or equal rates of support services as compared to those in nonpoor households. The National Foster Parent Association reports that as many as 60 percent of new foster parents quit in the first 12 months, ${ }^{6}$ and estimates indicate 40 percent of families that leave foster parenting do so primarily because of inadequate agency support. ${ }^{7}$ Providing ongoing support to foster parents can help guarantee that children do not suffer from frequent changes in placement.

One of the most common requests from foster parents is for respite care. ${ }^{8}$ Although most agencies have respite policies in place, foster parents often report that respite 
services are difficult to access because of inadequate numbers of respite caregivers. The National Foster Parent Association recommends that all foster parents receive at least two days per month of planned respite care. ${ }^{9}$ Although this guideline may be difficult for agencies to achieve because of limited resources, agencies should encourage unofficial respite to help ensure that all foster parents protect themselves from burnout. ${ }^{10}$ This could mean that agencies maintain listings of cleared babysitters, particularly those with expertise in caring for children with special needs or parents enroll youth in communitybased activities, such as sports or arts programs to give them a time to rest while their children are away. ${ }^{11}$ House and Senate leadership recently reached agreement on a bill, H.R.4980, that when passed will require states to support foster youths' participation in age appropriate social and enrichment activities and, starting in 2020, will provide some funds for those activities.

It is important to keep in mind that nonrelative foster parents have connections to official agencies before a child arrives and are likely to maintain a strong connection to the agency because of that initial connection. ${ }^{13}$ Furthermore, nonrelative foster parents may have had other foster children and be experienced in securing the support services they need from the agency. Although state policies differ, generally, formal kinship foster parents are eligible to receive many of the same services as nonrelative foster parents. ${ }^{14}$ But child welfare agencies often offer fewer support services to kin than to nonrelative foster parents, and kinship foster parents may request fewer support services because they (1) do not know what to request, (2) are afraid to make a request, or (3) want to avoid agency intrusion on their family. ${ }^{15}$ Kin also face barriers accessing support services because they face eligibility constraints, are unfamiliar with community resources, or encounter waiting lists. ${ }^{16}$ These barriers are likely exasperating for informal kinship foster parents. However, because federal law requires caseworkers to inform caregivers of the placement options, the child welfare agency should know who some informal caregivers are and be able to reach out to them to provide support services. ${ }^{17}$ Agencies could also reach out to voluntary informal kinship foster parents by placing advertisements in newspapers and public areas about the support services that are available.

Even in this era of limited resources, it is important to make sure that all foster parents (those in poor and nonpoor households), and particularly kinship foster parents, have access to adequate support services to help ensure that children in out-of-home placements are nurtured and that foster parents receive the support they need to continue their important work.

\section{Data}

The data for this analysis come from a national sample of children who had a child maltreatment report, the second National Survey of Child and Adolescent Well-Being (NSCAW II). Face-to-face interviews were conducted with children, parents, and nonparent adult caregivers (for example, foster caregivers, informal kinship caregivers, formal kinship caregivers). The data used in this analysis are from a sample of children who had a maltreatment report, and thus in most cases the state should have a record of who the informal caregiver is, although in some cases the informal foster care may have been arranged by the family after the investigation was complete and the case was closed. Baseline data collection began in March 2008 and was completed in September 2009. The second wave of data collection began eighteen months later (October 2009 to January 2011). The subsample for this analysis includes children, ages 0 to 18 years, who were in foster care during the second wave of data collection. ${ }^{18}$ A poor household was defined as one earning less than 100 percent of the federal poverty level $(n=315)$ and a nonpoor household was defined as one earning 100 percent or more of the federal poverty level $(n=914)$.

\section{Endnotes}

1. K. W. Rhodes, J. G. Orme, and C. Buehler, "A Comparison of Family Foster Parents Who Quit, Consider Quitting, and Plan to Continue Fostering," Social Service Review, vol. 75, no. 1 (2001): 84-114; M. Dozier et al., "Interventions for Foster Parents: Implications for Developmental Theory," Development and Psychopathology, vol. 4 (2002): 843-860.

2. Each year, approximately 250,000 children enter foster care and approximately 400,000 children are in foster care in any given year. The AFCARS report is available at www.acf. hhs.gov/sites/default/files/cb/afcarsreport19.pdf.

3. In some cases, children may be placed with informal kin because of a court order, or a parent may have voluntarily released legal custody temporarily or permanently, so that the informal kin have both physical and legal custody. Informal kinship care covers a wide variety of circumstances and varies by state. However, the children are usually in the physical custody of the relatives but remain in the legal custody of the parents. See U.S. Department of Health and Human Services, "Kinship Caregivers and the Child Welfare System" (Washington, DC: Children's Bureau/ACYF, 2010), available at www.childwelfare.gov/pubs/f_kinshi/f_kinshi.pdf.

4. U.S. Department of Health and Human Services, “The Placement of Children With Relatives" (Washington, DC: Children's Bureau/ACYF, 2010), available at www.childwelfare. gov/systemwide/laws_policies/statutes/placement.pdf.

5. The Friends National Resource Center for CommunityBased Child Abuse Prevention (CBCAP), "Respite and Crisis Care," Fact Sheet No. 14 (Chapel Hill, NC: CBCAP/U.S. 
Department of Health and Human Services/Administration for Children and Families, 2007), available at http://friendsnrc.org/ component/joomdoc/doc_details/76-respite-and-crisis-care.

6. Denise Goodman et al., "Recruitment, Training, and Support: The Essential Tools of Foster Care" (Baltimore, MD: The Annie E. Casey Foundation, 2002), available at https://one.centerschool.org/download.php?ID=539\&name=/FFRec.pdf.

7. Denise Goodman and Frank Steinfeild, "Building Successful Resource Families: A Guide for Public Agencies" (Baltimore, MD: The Annie E. Casey Foundation, 2012), available at www.aecf.org/ /media/ Pubs/Topics/Child\%20Welfare\%20Permanence/ Foster\%20Care/BuildingSuccessfulResourceFamilies/ BuildingSuccessfulResourceFamilies.pdf.

8. Ibid.

9. Ibid.

10. Ibid; Collaboration to AdoptUsKids, “Taking a Break: Creating Foster, Adoptive, and Kinship Respite in Your Community" (Linthicum, MD: Collaboration to AdoptUsKids, 2013), available at www.adoptuskids.org/_assets/files/ NRCRRFAP/resources/taking-a-break-respite-guide.pdf.

11. Denise Goodman and Frank Steinfeild, "Building Successful Resource Families: A Guide for Public Agencies" (Baltimore, MD: The Annie E. Casey Foundation, 2012), available at www.aecf.org/ /media/ Pubs/Topics/Child\%20Welfare\%20Permanence/ Foster\%20Care/BuildingSuccessfulResourceFamilies/ BuildingSuccessfulResourceFamilies.pdf.

12. See www.finance.senate.gov/newsroom/chairman/ release $/$ ?id=df426c5a-017f-4069-8c7b-fe2f1a7aff23.

13. R. Geen, "Foster Children Placed With Relatives Often Receive Less Government Help" (Washington DC: The Urban Institute, 2003), available at www.urban.org/ publications/310774.html.

14. A. Jantz et al. "The Continuing Evolution of State Kinship Care Policies” (Washington DC: The Urban Institute, Assessing the New Federalism Discussion Paper No. 02-11), available at www.urban.org/UploadedPDF/310597_state_kinship_care.pdf.

15. R. Geen, "Foster Children Placed With Relatives Often Receive Less Government Help" (Washington DC: The Urban Institute, 2003), available at www.urban.org/ publications/310774.html.

16. Ibid.

17. U.S. Department of Health and Human Services, "The Placement of Children With Relatives" (Washington, DC: Children's Bureau/ACYF, 2010), available at www.childwelfare. gov/systemwide/laws_policies/statutes/placement.pdf.

18. A two-staged cluster sampling strategy was used. Information on the second National Survey of Child and Adolescent Well-Being (NSCAW II) study design and sampling procedure has been previously published. See M. Dolan et al., "NSCAW II Baseline Report: Introduction to NSCAW II Final Report," OPRE Report No. 2011-27a (Washington, DC: Office of Planning, Research and Evaluation, Administration for Children and Families, U.S. Department of Health and Human Services, 2011), available at www.acf.hhs.gov/programs/opre/index.html.

\section{About the Authors}

Wendy A. Walsh is a research associate professor of sociology at the Crimes Against Children Research Center and a faculty fellow at the Carsey School of Public Policy at the University of New Hampshire (wendy.walsh@unh.edu).

Marybeth J. Mattingly is director of research on vulnerable families at the Carsey School of Public Policy and a research assistant professor of sociology at the University of New Hampshire (beth.mattingly@unh.edu).

\section{A cknowledgments}

We are grateful for the substantive and editorial comments and suggestions from Bruce Mallory, Curt Grimm, Amy Sterndale, Michael Ettlinger, and Laurel Lloyd at the Carsey School of Public Policy and Barbara Ray at HiredPen.

This document includes data from the National Survey on Child and Adolescent Well-Being, which was developed under contract with the Administration on Children, Youth, and Families, U.S. Department of Health and Human Services (ACYF/DHHS). The data have been provided by the National Data Archive on Child Abuse and Neglect. The information and opinions expressed herein reflect solely the position of the authors. Nothing herein should be construed to indicate the support or endorsement of its content by ACYF/DHHS.

\section{N1 University of New Hampshire Carsey School of Public Policy}

The Carsey School of Public Policy conducts policy research on vulnerable children, youth, and families and on sustainable community development. We give policy makers and practitioners timely, independent resources to effect change in their communities.

This work was supported by the Annie E. Casey Foundation.

Huddleston Hall

73 Main Street

Durham, NH 03824

(603) 862-2821

TTY USERS: DIAL 7-1-1 OR 1-800-735-2964 (RELAY N.H.)

carsey.unh.edu 